\title{
Current strategies for the diagnosis and management of chronic lymphocytic leukemia (CLL), with a focus on poor-risk CLL: A review
}

\author{
Kronik lenfositik lösemi (KLL) tanı ve tedavisine iliskin, özellikle yüksek \\ riskli KLL'ye odaklanan güncel stratejiler: Derleyici bir inceleme
}

\author{
Fabienne Mc Clanahan, Peter Dreger \\ Department of Internal Medicine V, University Hospital of Heidelberg, Heidelberg, Germany
}

\begin{abstract}
Despite substantial advancement in the understanding and treatment of chronic lymphocytic leukemia (CLL), a standard curative approach does not exist. The choice of treatment is generally based on the existence of biological and genetic factors associated with the prediction of prognosis, individual response to therapy, and duration of remission. About $20 \%$ of patients that require treatment have an aggressive disease course and die within a few years, despite early initiation of intensive therapy (poor-risk CLL). Poor-risk CLL can be predicted by the presence of genomic markers, and the quality and duration of response to purine-analogue-based treatment. Within this patient subgroup alternative treatment approaches such as alemtuzumab or new substances such as flavopiridol or IMiDs ${ }^{\circledR}$ should be considered. To date, the only treatment bearing curative potential is allogeneic stem cell transplantation; in contrast to conventional immunochemotherapy, it can provide long-term disease control, even in patients with del $17 \mathrm{p}$ or other unfavorable biological and clinical risk factors. The aim of this review was to outline the current strategies for the diagnosis and management of CLL, with a focus on high-risk CLL.

(Turk J Hematol 2011; 28: 86-96)
\end{abstract}

Key words: CLL, genetics, poor-risk, treatment, allogeneic stem cell transplantation

Received: March 17, 2011

Accepted: April 26, 2011

\section{Özet}

Kronik lenfositik löseminin (KLL) tanı ve tedavisine yönelik önemli gelişmelere karşın, şifa sağlayıcı (küratif) standart bir yaklaşım henüz bulunmamaktadır. Tedavi seçimi genellikle prognozu öngören biyolojik ve genetik faktörlerin varlığına, tedaviye alınan bireysel yanıt ve iyileşme (remisyon) süresine dayanır. Tedavi edilmesi gereken hastaların yaklaşık \%20'si hızla ilerleyen bir klinik gidis gösterirler ve yoğun tedaviye erkenden başlanmasına karşın birkaç yıl içerisinde yaşamlarını yitirirler (yüksek riskli KLL). Yüksek riskli KLL olasılığı, genomik belirteçler yanında purin-analogu temelli tedaviye alınan yanitın niteliği ve süresiyle önceden kestirilebilir. Bu hasta altgrubunda, alemtuzumab gibi alternatif tedavi yaklaşımları ya da flavopiridol ve IMiD $®$ grubu gibi yeni ilaçlar göz önüne alınmalıdır. Günümüzde bu hastalarda şifa sağlayıcı potansiyele sahip tek tedavi seçeneği allogeneik kök hücre naklidir. Bu yöntemle, geleneksel immünokemoterapinin aksine, del $17 \mathrm{p}$ veya diğer olumsuz biyolojik ve klinik risk faktörlerine sahip hastalarda bile hastalığın uzun süreli denetimi sağlanabilir. Bu derleyici incelemede, yüksek riskli KLL'ye odaklanarak KLL tanı ve tedavisine ilişkin güncel stratejilerin özetlenmesi amaçlanmıştır. (Turk J Hematol 2011; 28: 86-96)

Anahtar kelimeler: KLL, genetik, yüksek risk, tedavi, allogeneik kök hücre transplantasyonu 


\section{Epidemiology and Clinical Features}

Chronic lymphocytic leukemia (CLL) is one of the most common lymphoid malignancies, accounting for more than $10 \%$ of all lymphoid neoplasms, and is the most common adult leukemia in Western countries, with an age-adjusted annual incidence rate of about 4 cases per 100.000 men and women $[1,2]$. While the median age at diagnosis is over 70 years, approximately $30 \%$ of patients are diagnosed at an age of $\leq 65$ years. The disease has a slight male predominance (male:female ratio: 1.5-2:1). Clinical features are highly variable, and most patients are asymptomatic. As the disease proceeds, fatigue, splenomegaly, hepatomegaly, lymphadenopathy, and extranodal infiltrates are observed. Another hallmark is immune suppression and deficiency, including hypogammaglobulinemia, autoimmune phenomena, and impaired response to vaccination, which is further exacerbated by therapy-related immunosuppression [3].

\section{Diagnosis}

To unify the criteria for diagnosis and response assessment a working group sponsored by the National Cancer Institute first published guidelines for the design and conduct of clinical trials on CLL in 1988 [4]. Following an update in 1996, the International Workshop on CLL (iwCLL) revised the guidelines, taking into account the substantial progress that had been made in the understanding and treatment of the disease [5]. The recommendations for diagnosis and treatment discussed in this review are based on the iwCLL criteria.

The diagnosis of CLL requires the presence of cells with a CLL-specific immunophenotype, along with $\geq 5.000$ B-lymphocytes $\mu \mathrm{L}^{-1}$ in peripheral blood [5]. The presence of CLL cells with a lower B-lymphocyte count in the absence of lymphadenopathy, organomegaly, or cytopenia is now defined as monoclonal B-lymphocytosis (MBL) [6]. The presence of lymphadenopathy or splenomegaly, and a B-lymphocyte count $\leq 5.000 \mu \mathrm{L}^{-1}$ is defined as small lymphocytic lymphoma (SLL). More than 55\% prolymphocytes in the blood suggests a diagnosis of B-cell prolymphocytic leukemia (B-PLL) [7].

Flow cytometry is essential for determining the clonality of B-lymphocytes and the following characteristic CLL-cell-surface phenotypes: the presence of CD19, CD5, CD23 and CD43, weak expression of CD20 and CD79b, and kappa or lambda immunoglobulin light chains [8,9]. The expression of CD38 is variable, but has prognostic significance and should therefore be evaluated $[10,11]$. Flow cytometry is also indispensable for differentiating CLL from other lymphoproliferative diseases, such as hairy cell leukemia, leukemic manifestations of mantle cell lymphoma, marginal zone lymphoma, splenic marginal zone lymphoma, and follicular lymphoma.

Bone marrow investigation is generally not required for the diagnosis of CLL, especially in patients without cytopenia and those not requiring treatment. Bone marrow aspiration and biopsy may be indicated, however, when treatment is required, as the extent and pattern (diffuse vs. non-diffuse) of bone marrow infiltration can provide valuable information on tumor burden and factors that may contribute to cytopenia. Post-treatment bone marrow investigation is recommended in patients with persisting cytopenia of unknown origin. In SLL the diagnosis should be verified via histopathological evaluation of a lymph node biopsy specimen.

\section{Clinical Staging and Prognosis}

As the clinical course of CLL varies widely, staging systems have been developed to stratify patients into different risks groups for predicting survival. The 2 most commonly used are the Rai and Binet staging systems [12,13]. Both systems consist of parameters that are obtained via clinical examination and standard laboratory tests, and are therefore easy to obtain. Ultrasound and computed tomography are not required, although they increase the accuracy of the assessment of intra-abdominal lymph nodes and organomegaly. Table 1 outlines the parameters that define the clinical stages. To account for extreme heterogeneities observed within each risk group, Wierda et al. proposed a new prognostic index for previously untreated CLL patients for predicting overall survival (OS) [14]: in the Rai staging system age, absolute lymphocyte count, gender, $\beta 2$-microglobulin concentration, and the number of involved lymph nodes were independently associated with OS. This index was validated in an independent patient cohort by a Mayo Clinic study [15]. A recent observational database study by GIMEMA (Gruppo Italiano Malattie EMatologiche dell'Adulto) also confirmed the utility of the index for predicting time to first treatment [16].

\section{Indications for Treatment}

As there is no standard curative approach for CLL, the decision to begin treatment is based on the development of symptoms and disease activity. Newly diagnosed asymptomatic patients should be monitored without therapy, as there is no documented benefit from early anti-leukemic treatment [5]. Patients with symptomatic, advanced, or rapidly pro- 
Table 1. Rai and Binet clinical staging

\begin{tabular}{|c|c|c|}
\hline Risk group & Rai & Binet \\
\hline Low & $\begin{array}{l}\text { 0: lymphocytosis with CLL cells in PB and/or } \\
\text { BM, lymphoid cells }>30 \%\end{array}$ & $\begin{array}{l}\text { A: } \mathrm{Hb} \geq 100 \mathrm{~g} \mathrm{~L}^{-1}\left(10 \mathrm{~g} \mathrm{dL}^{-1}\right) \text {, platelet count } \\
\geq 100 \times 10^{9} \mathrm{~L}^{-1} \text {, and up to } 2 \text { lymph node areas involved* }\end{array}$ \\
\hline Intermediate & $\begin{array}{l}\text { 1/2: Lymphocytosis, enlarged lymph nodes at any } \\
\text { site, splenomegaly and/ or hepatomegaly }\end{array}$ & $\begin{array}{l}\text { B: } \mathrm{Hb} \geq 100 \mathrm{~g} \mathrm{~L}^{-1}\left(10 \mathrm{~g} \mathrm{dL}^{-1}\right), \text { platelet count } \\
\geq 100 \times 10^{9} \mathrm{~L}^{-1} \text {, and organomegaly greater than that } \\
\text { defined for stage A (i.e. } \geq 3 \text { areas of nodal or organ } \\
\text { enlargement) }\end{array}$ \\
\hline High & $\begin{array}{l}\text { 3/4: Disease-related anemia }\left(\mathrm{Hb}<110 \mathrm{~g} \mathrm{~L}^{-1}\right. \\
\left.\left.\left[11 \mathrm{~g} \mathrm{dL}^{-1}\right]\right) \text { or thrombocytopenia (plt }<100 \times 10^{9} \mathrm{~L}^{-1}\right)\end{array}$ & $\begin{array}{l}\text { C: } \mathrm{Hb}<100 \mathrm{~g} \mathrm{~L}^{-1}\left(10 \mathrm{~g} \mathrm{dL}^{-1}\right) \text { and/or a platelet count } \\
<100 \times 10^{9} \mathrm{~L}^{-1} \text {, irrespective of organomegaly }\end{array}$ \\
\hline \multicolumn{3}{|c|}{$\begin{array}{l}\text { *Areas of involvement considered for staging } \\
1 \text {. Head and neck, including the Waldeyer ring (this counts as } 1 \text { area, even if }>1 \text { group o } \\
\text { 2. Axillae (involvement of both axillae counts as } 1 \text { area) } \\
\text { 3. Groins, including superficial femorals (involvement of both groins counts as } 1 \text { area) } \\
\text { 4. Palpable spleen } \\
\text { 5. Palpable liver }\end{array}$} \\
\hline
\end{tabular}

gressive disease usually benefit from treatment. Definitions of disease activity are listed in Table 2 . The decision to begin second-line treatment generally follows the same guidelines.

\section{Factors Guiding the Choice of Treatment}

\section{Physical fitness and comorbidity}

Once treatment is indicated, each patient's individual physical condition and degree of co-morbidity should be evaluated. In completely independent patients with no comorbidity and otherwise normal life expectancy (go-go patients) aggressive chemotherapy aimed at the prolongation of survival is recommended. The goal in patients with some co-morbidity, impaired organ function, and reduced performance status (slow-go patients) is to achieve disease remission via a less aggressive approach. Patients that are severely handicapped and have high comorbidity (no-go patients) might often fare best with supportive palliative care only. Physical fitness can be determined empirically or by using the cumulative illness rating scale (CIRS) [17].

\section{Biological prognostic factors}

Substantial progress has been made in the identification of biological and genetic factors that are strongly associated with the prediction of prognosis, individual response to therapy, and duration of remission. Several studies reported that elevated serum thymidine kinase (sTK), $\beta 2$-microglobulin, and soluble CD23 may predict OS or progression-free survival (PFS) [18-21]. Using fluorescence in-situ hybridization (FISH) cytogenetic aberrations can be identified in more than $80 \%$ of CLL patients [22]. The most common chromosomal aberrations are del 13q, del 11q, trisomy 12 , del $17 \mathrm{p}$, and del $6 \mathrm{q}$, with $13 \mathrm{q}$ deletion indi-
Table 2. Definitions of disease activity

\section{At least 1 of the following:}

1. Evidence of progressive marrow failure: anemia and/or thrombocytopenia

2. Massive (i.e. $\geq 6 \mathrm{~cm}$ below the left costal margin) or progressive or symptomatic splenomegaly

3. Massive nodes (i.e. $\geq 10 \mathrm{~cm}$ in diameter), or progressive or symptomatic lymphadenopathy

4. Progressive lymphocytosis with an increase $>50 \%$ over a 2 -month period, or lymphocyte doubling time (LDT) $<6$ months.

5. Autoimmune anemia and/or thrombocytopenia

6. Constitutional symptoms: unintentional weight loss, significant fatigue, fevers, night sweats

cating the best prognosis with a median survival of $>10$ years and $17 p$ deletion indicating a particularly poor prognosis with a median survival of $<3$ years, even with modern fludarabine/rituximab-based frontline treatments.

Somatic mutations in the gene encoding the variable region of the heavy chain of immunoglobulins (IGHV) occur in approximately $50 \%$ of CLL patients [23]. Patients lacking a mutation in this region (unmutated IGHV) tend to have a more progressive and advanced form of CLL than patients with mutated IGHV. This was first shown retrospectively in patients treated in the pre-purine-analogue era, but has been confirmed in prospective studies using fludarabine combination regimens [11,24]. As testing for IGHV mutation status is complex and expensive, ZAP-70 expression was reported to correlate with the expression of unmutated IGHV [11,24,25]; however, the association between ZAP-70 and IGHV is not definitive. According to the iwCLL guidelines, with the exception of del 17p FISH, these tests should not 
be used in general practice to guide clinical decision-making; however, it is essential to consider the existence and importance of these tests at the time of first diagnosis.

\section{First-line Treatment}

\section{Go-go patients without del $\mathbf{1 7 p}$}

Following traditional treatment approaches consisting of alkylating agents (mostly cyclophosphamide or chlorambucil) with or without nucleoside analogue-based substances, the combination of monoclonal antibodies with chemotherapy increased the complete response (CR) rate from $4 \%$ [26] to 70\% [27-30]. A large phase III trial that randomly assigned patients to 6 courses of fludarabine and cyclophosphamide (FC), or rituximab-FC (R-FC) was conducted by the German CLL Study Group (GCLLSG) (CLL8 trial). At 3 years post treatment, $65 \%$ of the patients in the chemoimmunotherapy group were progression free, compared to $45 \%$ in the chemotherapy group (HR:.56; 95\% CI: .46-.69; p<0.0001) [31]. Additionally, 3-year OS was significantly longer in the R-FC group ( $87 \%$ vs. $83 \%, \mathrm{p}=0.01$ ), and R-FC treatment was associated with a significantly higher complete remission (CR) rate and longer duration of response. Although R-FC was more frequently associated with grade 3 and 4 neutropenia and leucopenia, it is now considered the gold standard treatment for physically fit patients without $17 p$ deletion. In another GCLLSG phase II trial previously untreated patients received 6 cycles of bendamustine ( $90 \mathrm{mg} \mathrm{m}^{-2}$ on $\mathrm{d} 1$ and 2) with rituximab $\left(375 \mathrm{mg} \mathrm{m}^{-2}\right.$ for the first cycle and $500 \mathrm{mg} \mathrm{m}^{-2}$ for subsequent cycles, repeated every $28 \mathrm{~d}$ ) (R-B regimen) [32]. The overall response (OR) rate was $91 \%$, including $33 \%$ of patients with CR. Hematopoietic and overall toxicity of R-B was modest. After 18 months $76 \%$ of the patients were still in remission, while median progression-free survival (PFS) had not been reached. R-B can therefore be considered safe and effective. The GCLLSG is currently conducting a randomized phase III trial to make a direct comparison of R-B and R-FC.

Variations of the R-FC regimen have been tested extensively. For example, Bosch et al. conducted a phase II trial with 29 previously untreated CLL patients receiving rituximab plus FCM (mitoxantrone), followed by rituximab maintenance every 3 months for up to 2 years [33]. The OR, MRD- (minimal residual disease) negative CR, MRD-positive $\mathrm{CR}$, and PR rates were 93\%, 46\%, 36\%, and 11\%, respectively, proving the efficacy of the regimen.
Another approach was substitution of fludarabine by pentostatine (R-PC). A phase III randomized trial of R-FC versus R-PC in previously untreated and minimally treated CLL patients showed that there weren't any statistical differences between OS, response, or infection rates [34].

The role of autologous stem cell transplantation

Autologous hematopoietic stem cell transplantation (autoHSCT) is considered an attractive treatment alternative for a select group of patients. Pioneers in the field of autoHSCT for CLL are Gribben et al. from the Dana Faber Cancr Center [35]. An update published in 2005 showed that relapses continued to occur after 10 years of followup, translating into a 6-year PFS of $30 \%$ and a 6 -year OS of 58\% [36]. In the MRC pilot study, a large multicenter phase II trial on autoHSCT as a coponent of first-line CLL treatment, the 5-year OS and PFS rates were $78 \%$ and $52 \%$, respectively [37]. An update of the GCLLSG CLL3 study, which had a similar design, reported a median OS of 10.5 years and a median PFS of 6.8 years after early autoHSCT [38]. The first, and to date, only phase III randomized trial was conducted by the EBMT; 39 patients with CR after first- or second-line treatment were randomized to consolidating autoHSCT or observation. Median event-free survival (EFS) was 24.4 months (range: 16.7-32 months) in the observation group and 51.2 months (range: 39.8-62.5 months) in the autoHSCT group, indicating a 5-year EFS of $24 \%$ and $42 \%$, respectively. While autoHSCT almost doubled event-free survival (EFS) and time to retreatment, there wasn't a significant difference in OS (5-year OS was $84 \%$ and $86 \%$, respectively). In addition, several studies indicate that autoHSCT fails to achieve durable MRD negativity [40,41], which means that autoHSCT cannot be considered as a curative treatment in CLL. Moreover, long-term follow-up observations have raised concerns about the increased incidence of therapy-related myeloid neoplasms (MDS and AML) following autoHSCT. In the Dana Faber and MRC series the 5- and 8-year incidence of therapy-related myeloid neoplasms was $12 \%$ [36,42], versus a 10 -year incidence rate of $8 \%$ in the CLL3 trial [38]. Due to these limitations, autoHSCT cannot be recommended as a standard approach in CLL and should only be used in clinical trials.

\section{Go-go patients with del $17 p$}

As patients carrying del 17p have a high risk of very poor outcome with fludarabine-based regimens that include bendamustine, alternative treatment 
approaches should be considered. It is well known that alemtuzumab has a similar affect in del 17p and non-del 17p CLL patients [43]. In the ongoing prospective GCLLSG CLL2o study patients with del 17p or refractoriness to fludarabine received subcutaneous alemtuzumab combined with oral dexamethasone, followed by alemtuzumab maintenance or allogeneic hematopoietic stem cell transplantation (alloHSCT). As of September 2010, 80 patients were enrolled in the protocol, of which 31 without prior therapy had del 17p and 17 that relapsed had del 17p [44]. OR and CR were $100 \%$ and $23 \%$, respectively, in the del $17 \mathrm{p}$ first-line group, which are considerably higher than those in the CLL8 study F-CR group (71\% and $5 \%$, respectively). Adverse events were hematotoxicity and grade $3 / 4$ cytomegaly virus (CMV) infection (16\%); however, the response duration following alemtuzumab is usually limited, making the search for effective first-line consolidation mandatory. To date, the only treatment with the potential for longterm disease control in the del 17p patient subgroup is alloHSCT, which will be discussed in detail below.

\section{Slow-go patients with and without del 17p}

Patients with relevant comorbidity may be offered chlorambucil, bendamustine, or a dose-reduced fludarabine-containing regimen, with or without rituximab, depending on the fragility of the patient $[45,46]$. Alemtuzumab can also be considered in appropriate patients (i.e. those with del 17p). The GCLLSG is currently conducting an open-label 3 -arm randomized phase III trial to compare the efficacy and safety of the new monoclonal CD20 antibody RO5072759 (GA101) plus chlorambucil (GClb) to those of rituximab plus chlorambucil (RClb) or chlorambucil only (Clb) in previously untreated patients with comorbidity.

\section{Second-line Treatment}

For selecting the appropriate indication and regimen for salvage treatment, the same criteria for first-line therapy primarily apply; start only if symptoms or rapid lymphoproliferation are present, and consider comorbidity and the presence of del 17p. In addition, an important factor guiding the choice of salvage treatment is the quality and duration of response to the previous treatment line; patients that relapse $>12$ months after purine analogue monotherapy or 24 months after completion of a modern combination treatment might benefit from repetition or modest escalation of the previous regimen, e.g. R-FC after F or FC, and R-B after R-FC.
Before starting second-line treatment reassessment of $17 \mathrm{p}$ status is highly recommended to avoid unnecessary exposure to ineffective drugs in cases of clonal evolution. In contrast, all patients that relapse sooner must be regarded as having poorrisk CLL and treated accordingly.

\section{Definition of Poor-Risk CLL}

About $20 \%$ of patients with CLL that require treatment have an aggressive course and die within a few years of diagnosis, despite early initiation of intensive therapy. The hallmark of this so called poor-risk CLL is pre-existent or rapid development of resistance to the current standard combination regimens. Poor-risk CLL can be partially predicted by the presence of defined genomic markers.

\section{Molecular markers}

As outlined above, the existence of del $17 p$ is associated with poor prognosis [22]. Patients with $17 p$ deletion are often resistant to standard chemotherapy regimens. Following initial results of retrospective analyses [47], the adverse impact of del 17p was confirmed by several prospective phase III clinical trials using purine-analogue-based therapy. The LRF CLL4 trial that included 777 CLL patients that required treatment reported that patients with del $17 \mathrm{p}$ had significantly poorer response to fludarabinebased treatment and shorter PFS [28]. In a Spanish trial del 17p was associated with a significantly lower CR rate [33], and in the GCLLSG CLL4 (F vs. FC) and CLL8 trials (FC vs. FCR) del 17p was associated with dramatically lower CR, OR, OS, and PFS [31].

Recent data suggest that the vast majority of patients with del $17 \mathrm{p}$ had mutations of the remaining allele of the TP53 gene located in the deleted region of 17p [48]. Whereas TP53 mutations in general led to significantly shorter survival $(p=0.002)$, survival was equally poor in patients with TP53 mutation only (5.5 months), TP53 mutation plus del 17p (7.6 months), and del $17 \mathrm{p}$ only (5.4 months). In a recent analysis of the GCLLSG CLL4 trial (F vs. FC) TP53 mutation was observed in $8.5 \%$ of the patients, of which $4.5 \%$ did not have del 17p [49]. None of the patients with TP53 mutation achieved CR, and median PFS and OS were significantly shorter in the group with TP53 mutation $(p<0.001)$. As the outcome of patients with del 17p and/or TP53 mutation-both individually and combined-was very poor, it was recently proposed that these patients be considered as ultra-high risk [50].

In 2010 Oscier et al. published a comprehensive report on the prognostic significance of age, gender, and biomarkers in the prediction of treatment 
response, PFS, and OS reported by a prospective randomized British CLL4 trial [51]. Using the factors identified as independent predictors for PFS, they subdivided CLL4 patients into 3 risk groups: $6 \%$ with known TP53 loss >10\% were considered poor risk and $72 \%$ without TP53 loss and at least 1 of the following factors-unmutated IGHV, IGHV3-21 usage, 11q deletion, and/ or $\beta-2$ microglobulin $>4 \mathrm{~m} \mathrm{~L}^{-1}$-were considered intermediate risk. In all, $22 \%$ of patients were considered good risk, defined as none of the above factors and mutated IGHV. The 5-year PFS rates in these 3 groups were $0 \%, 12 \%$, and $34 \%$, respectively, and the corresponding 5 -year OS rates were $9 \%, 53 \%$ and $79 \%$, respectively, which confirmed the poor outcome of patients with del 17p and the prognostic impact of unmutated IGHV, $\beta 2$-microglobulin, and 11q deletion. As this is a novel approach to risk stratification in CLL, it needs to be validated in patient cohorts treated with newer combination therapies, including monoclonal antibodies.

Response to treatment and duration of remission Independent of the presence of genomic poor-risk markers, the overriding predictor of poor-risk disease is the response to purine-analogue-based treatment. According to the iwCLL guidelines, every clinical response that is not CR or PR (e.g. stable disease, non-response, or progressive disease) should be rated as a treatment failure. Refractory disease is defined as treatment failure or disease progression within 6 months of the completion of the last antileukemic treatment. Early data from the M.D. Anderson Cancer Center on 174 patients with progressive or advanced CLL that received first-line therapy with fludarabine or fludarabine combined with prednisone showed that patients that did not achieve a clinical response had significantly shorter OS [52]. Patients with residual disease or nonresponse after fludarabine combined with cyclophosphamide and rituximab (R-FC) also had significantly reduced OS [30].

Median survival was also significantly reduced in patients that initially responded to R-FC, but then relapsed within 36 months, as compared to those that relapsed $\geq 36$ months after $\mathrm{R}-\mathrm{FC}$ treatment $(\mathrm{p}<0.0001)$ [53]. In an analysis of the CLL8 trial R-FC patients with PFS of $12-24$ months $(n=43)$ had a median post-relapse OS of $<40$ months. Outcomes for relapsing patients treated with $\mathrm{FC}$ within the same time interval were even worse [54].

The poor-risk associated with resistant disease is reflected in both the iwCLL guidelines and the EBMT (European Group for Blood and Marrow Transplantation) transplant consensus. According to
iwCLL, patients with resistant disease (defined as a short time to progression after the first treatment) and/or leukemia cells with del 17p should be offered alternative treatment approaches such as alloHSCT. According to the EBMT consensus, patients with non-response or early relapse (within 12 months) after purine analogue treatment relapse within 24 months of having achieved a response with purine-analogue-based combination therapy, or autologous transplantation and TP53 abnormalities requiring treatment are potential candidates for alloHSCT [55].

\section{Treatment of Poor-Risk CLL}

As outlined in detail above, stable disease, nonresponse, progressive disease, and refractory disease are predictors of poor survival, and such patients should be considered high-risk, regardless of pre-existing biomarkers. This means that patients that have not been considered for alemtuzumab or alloHSCT pre-treatment based on their cytogenetic risk profile are candidates for a more intensive approach based on their inadequate response to first-line treatment. Most importantly, it is crucial to change the treatment components used in the initial failed approach. There are several treatment options, including alemtuzumab, ofatumumab, experimental drugs, and alloHSCT.

The phase II GCLLSG CLL2H trial evaluated the safety and efficacy of subcutaneous alemtuzumab in patients with fludarabine-refractory CLL, and reported that OR was 34\% (4\% CR and 30\% PR), median PFS was 7.7 months, and median OS was 19.1 months [56]. Efficacy did not vary significantly between genetic subgroups, indicating that alemtuzumab treatment could overcome the adverse prognostic impact of IGHV mutation status, TP53 mutation, and genomic aberrations. The potential benefit of alemtuzumab in combination with chemotherapy was first observed in 6 patients by Kennedy et al. [57]; their findings were confirmed by a phase II trial on relapsed or refractory CLL, which reported an OR of $83 \%$, including 11 patients with $\mathrm{CR}$, and resolution of disease in all affected sites [58].

In the ongoing GCLLSG CLL2o trial on the combination of alemtuzumab and high-dose dexamethasone, 31 of the 80 patient enrolled to date were fludarabine-resistant; their OR rate was $47 \%$, none achieved CR, and 12-month OS was 54\% [44]. A recently published interim analysis of an international phase II study on the efficacy of the human monoclonal CD20 antibody ofatumumab in 138 patients that were fludarabine- and alemtuzumab- 
refractory reported an OR rate of 58\%; median PFS and OS were 5.7 and 13.7 months, respectively, indicating that ofatumumab might be a promising treatment option for fludarabine-refractory patients with poor-prognosis CLL [59]. Alternative treatment approaches using new substances, such as flavopiridol or IMiDs ${ }^{\circledR}$, are currently being tested in clinical trials, and some patients might be eligible for inclusion in phase I or II clinical studies; however, none of the current or novel approaches has the potential for long-term disease control, highlighting the need for effective consolidation once remission is achieved.

\section{The role of Allogeneic Stem Cell Transplantation}

On the basis of its capacity to induce graft-versus-leukemia (GVL) effects [60], alloHSCT has been shown to provide long-term disease control in selected CLL patients [36,61-68]. Key outcome data from selected prospective clinical trials on reducedintensity conditioning (RIC) are summarized in Table 3. To elucidate the effect of alloHSCT in patients with del 17p, the EBMT performed a retrospective database analysis in which 44 patients with del 17p that received alloHSCT were identified [69]. After a median post-alloHSCT observation time of 39 months, 19 patients were still alive. Three-year OS and PFS rates were $44 \%$ and $37 \%$, respectively, and the cumulative incidence of disease progression at 4 years was 34\%. During 4 years of follow-up no late relapses occurred in 9 patients, indicating that alloHSCT might have curative potential in patients with del 17p.

The final results of the prospective GCLLSG CLL3X trial on the feasibility and efficacy of RIC
alloHSCT in patients with poor-risk CLL were recently published [70]. After a median follow-up of 46 months (7-102 months), 4-year non-relapse mortality (NRM), EFS, and OS were $23 \%, 42 \%$, and $65 \%$, respectively. Among the 52 patients for whom MRD monitoring results were available, 27 (52\%) were alive and MRD negative 12 months after transplantation. EFS was similar in all genetic subgroups, including patients with del $17 \mathrm{p}$. Multivariate analysis showed that uncontrolled disease at the time of alloHSCT and in vivo T-cell depletion with alemtuzumab, but no del 17p, previous purine analogue refractoriness, and donor source (human leukocyte antigen-identical siblings or unrelated donors) had an adverse impact on EFS and OS, indicating that alloHSCT can result in long-term MRD-negative survival in up to $50 \%$ of patients, independent of the underlying genomic risk profile. A recent update of the CLL3X data with work-up of TP53 mutation status showed that the adverse impact of TP53 mutation, similarly as del $17 \mathrm{p}$, can be overcome by alloHSCT [71].

Although controlled trials are lacking, currently available data strongly suggest that alloHSCT is the only therapy with curative potential in high-risk CLL. In contrast to conventional immunochemotherapy, it can provide long-term disease control, even in patients with del $17 \mathrm{p}$ or other unfavorable biological and clinical risk factors.

\section{Conclusions}

Substantial progress has been made in the understanding and treatment of CLL, and advances in

Table 3. Results of prospective clinical trials on reduced-intensity conditioning (RIC) alloHSCT in CLL

\begin{tabular}{|c|c|c|c|c|c|c|}
\hline & $\begin{array}{l}\text { Schetelig } \\
\text { et al. (61) }\end{array}$ & $\begin{array}{c}\text { Sorror } \\
\text { et al. (67) }\end{array}$ & $\begin{array}{c}\text { Khouri } \\
\text { et al. (65) }\end{array}$ & $\begin{array}{c}\text { Brown } \\
\text { et al. (66) }\end{array}$ & $\begin{array}{c}\text { Delgado } \\
\text { et al. (68) }\end{array}$ & $\begin{array}{c}\text { Dreger } \\
\text { et al. (70) }\end{array}$ \\
\hline Number of patients & 30 & 82 & 39 & 46 & 41 & 90 \\
\hline Conditioning regimen & $\mathrm{FB} / \mathrm{ATG}^{\mathrm{a}}$ & $\mathrm{F} / \mathrm{TBI} 2^{\mathrm{b}}$ & $\mathrm{FCR}+/-\mathrm{ATG}^{\mathrm{C}}$ & FBd $^{d}$ & FM/CD52e & $\mathrm{F} / \mathrm{C}+/-\mathrm{ATG}^{\mathrm{f}}$ \\
\hline Proportion of alternative donorsg & $57 \%$ & $37 \%$ & $18 \%$ & $67 \%$ & $41 \%$ & $60 \%$ \\
\hline 4-year PFS & $58 \%$ & $39 \%(5 y)$ & $44 \%$ & $34 \%(2 \mathrm{y})$ & $45 \%(2 y)$ & $42 \%$ \\
\hline 4-year OS & $69 \%$ & $50 \%(5 y)$ & $48 \%$ & $54 \%(2 y)$ & $51 \%(2 y)$ & $65 \%$ \\
\hline 4-year NRM & $15 \%$ & $23 \%(5 y)$ & n.r. & $17 \%(2 \mathrm{y})$ & $26 \%(2 y)$ & $23 \%$ \\
\hline Extensive chronic GVHD & $21 \%$ & $49-53 \%$ & $58 \%$ & $38 \%$ & $5 \%$ & $14 \%$ \\
\hline Median follow-up [years] (range) & $3.7(2.1-5.6)$ & 5 & $2.3(.3-6.7)$ & 1.7 & $1.3(0-5.2)$ & $3.8(0.6-8.5)$ \\
\hline
\end{tabular}

aFludarabine, busulfan, anti-thymocyte globulin (ATG)

b Fludarabine, total body irradiation $2 \mathrm{~Gy}$

cFludarabine, cyclophosphamide, rituximab plus ATG in alternative donor transplants

dFludarabine, busulfan

eludarabine, melphalan, alemtuzumab

f Fludarabine, cyclophosphamide plus ATG in alternative donor transplants

gDonor other than HLA-identical siblings

NRM: non-relapse mortality, GVHD: graft-versus-host disease 
molecular profiling of the disease have enabled physicians to better predict patient risk profiles and response to therapy. Several studies have validated the components and impact of poor-risk CLL, and international guidelines have implemented these criteria in their treatment recommendations. As a result, Poor-risk patients can now be identified with greater accuracy and offered intensified treatment options, such as allo HSCT or alemtuzumab. Depending on patient performance status, personal preference, and the availability of a stem cell donor, these treatment options offer a tailored treatment approach, providing an opportunity to cure CLL in this poor-risk population.

\section{Conflict of interest statement}

The authors of this paper have no conflicts of interest, including specific financial interests, relationships, and/or affiliations relevant to the subject matter or materials included.

\section{References}

1. Sant M, Allemani C, Tereanu C, De Angelis R, Capocaccia R, Visser O, Marcos-Gragera R, Maynadié M, Simonetti A, Lutz JM, Berrino F. Incidence of hematologic malignancies in Europe by morphologic subtype: results of the HAEMACARE project. Blood 2010;116:3724-34.

2. Altekruse SF, Kosary CL, Krapcho M, Neyman N, Aminou R, Waldron W, Ruhl J, Howlader N, Tatalovich Z, Cho H, Mariotto A, Eisner MP, Lewis DR, Cronin K, Chen HS, Feuer EJ, Stinchcomb DG, Edwards BK (eds). SEER Cancer Statistics Review, 1975-2007, National Cancer Institute. Bethesda, MD, http://seer.cancer.gov/ csr/1975 2007/, based on November 2009 SEER data submission, posted to the SEER web site, 2010.

3. Morrison VA. Infectious complications of chronic lymphocytic leukaemia: pathogenesis, spectrum of infection, preventive approaches. Best Pract Res Clin Haematol 2010; 23: 145-53.

4. Cheson BD, Bennett JM, Rai KR, Grever MR, Kay NE, Schiffer CA, Oken MM, Keating MJ, Boldt DH, Kempin $\mathrm{SJ}$, et al. Guidelines for clinical protocols for chronic lymphocytic leukemia: Recommendations of the national cancer institute-sponsored working group. American Journal of Hematology 1988;29:152-63.

5. Hallek M, Cheson BD, Catovsky D, Caligaris-Cappio F, Dighiero G, Döhner H, Hillmen P, Keating MJ, Montserrat E, Rai KR, Kipps TJ; International Workshop on Chronic Lymphocytic Leukemia. Guidelines for the diagnosis and treatment of chronic lymphocytic leukemia: a report from the International Workshop on Chronic Lymphocytic Leukemia updating the National Cancer Institute-Working Group 1996 guidelines. Blood 2008;111:5446-56.
6. Rawstron AC, Bennett FL, O'Connor SJ, Kwok M, Fenton JA, Plummer M, de Tute R, Owen RG, Richards SJ, Jack AS, Hillmen P. Monoclonal B-Cell Lymphocytosis and Chronic Lymphocytic Leukemia. New England Journal of Medicine 2008;359:575-83.

7. Müller-Hermelink HK, Montserrat E, Catovsky D, Campo E, Harris NL, Stein H. Chronic lymphocytic leukaemia/ small lymphocytic leukaemia. In: Swerdlow $\mathrm{SH}$, Campo E, Harris NL, et al. eds. WHO Classification of tumours of haematopoietic and lymphoid tissues. 4th Edition ed. Lyon: International Agency for Research on Cancer (IARC), 2008.

8. Moreau EJ, Matutes E, A'Hern RP, et al. Improvement of the chronic lymphocytic leukemia scoring system with the monoclonal antibody SN8 (CD79b). Am J Clin Pathol 1997; 108:378-82.

9. Ginaldi L, De Martinis M, Matutes E, Farahat N, Morilla $\mathrm{R}$, Catovsky D. Levels of expression of CD19 and CD20 in chronic B cell leukaemias. Journal of Clinical Pathology 1998;51:364-9.

10. Damle RN, Wasil T, Fais F, Ghiotto F, Valetto A, Allen SL, Buchbinder A, Budman D, Dittmar K, Kolitz J, Lichtman SM, Schulman P, Vinciguerra VP, Rai KR, Ferrarini M, Chiorazzi N. Ig V Gene Mutation Status and CD38 Expression As Novel Prognostic Indicators in Chronic Lymphocytic Leukemia. Blood 1999;94:1840-7.

11. Hamblin TJ, Orchard JA, Ibbotson RE, Davis Z, Thomas PW, Stevenson FK, Oscier DG. CD38 expression and immunoglobulin variable region mutations are independent prognostic variables in chronic lymphocytic leukemia, but CD38 expression may vary during the course of the disease. Blood 2002;99:1023-9.

12. Binet JL, Auquier A, Dighiero G, Chastang C, Piguet H, Goasguen J, Vaugier G, Potron G, Colona P, Oberling F, Thomas M, Tchernia G, Jacquillat C, Boivin P, Lesty C, Duault MT, Monconduit M, Belabbes S, Gremy F. A new prognostic classification of chronic lymphocytic leukemia derived from a multivariate survival analysis. Cancer 1981;48:198-206.

13. Rai KR, Sawitsky A, Cronkite EP, Chanana AD, Levy RN, Pasternack BS. Clinical staging of chronic lymphocytic leukemia. Blood 1975;46:219-34.

14. Wierda WG, O'Brien S, Wang X, et al. Prognostic nomogram and index for overall survival in previously untreated patients with chronic lymphocytic leukemia. Blood 2007;109:4679-85.

15. Shanafelt TD, Jenkins G, Call TG, Zent CS, Slager S, Bowen DA, Schwager S, Hanson CA, Jelinek DF, Kay NE. Validation of a new prognostic index for patients with chronic lymphocytic leukemia. Cancer 2009;115:363-72.

16. Molica S, Mauro FR, Callea V, Giannarelli D, Lauria F, Rotoli B, Cortelezzi A, Liso V, Foà R. The utility of a prognostic index for predicting time to first treatment in early chronic lymphocytic leukemia: the GIMEMA experience. Haematologica 2010;95:464-9.

17. Extermann M, Overcash J, Lyman GH, Parr J, Balducci L. Comorbidity and functional status are independent in older cancer patients. Journal of Clinical Oncology 1998;16:1582-7.

18. Hallek M, Langenmayer I, Nerl C, Knauf W, Dietzfelbinger H, Adorf D, Ostwald M, Busch R, Kuhn-Hallek I, Thiel E, 
Emmerich B. Elevated Serum Thymidine Kinase Levels Identify a Subgroup at High Risk of Disease Progression in Early, Nonsmoldering Chronic Lymphocytic Leukemia. Blood 1999;93:1732-7.

19. Hallek M, Wanders L, Ostwald M, Busch R, Senekowitsch R, Stern S, Schick HD, Kuhn-Hallek I, Emmerich B. Serum ss2-Microglobulin and Serum Thymidine Kinase are Independent Predictors of Progression-Free Survival in Chronic Lymphocytic Leukemia and Immunocytoma. Leukemia \& Lymphoma 1996;22:439-47.

20. Reinisch W, Willheim M, Hilgarth M, Gasché C, Mader R, Szepfalusi S, Steger G, Berger R, Lechner K, BoltzNitulescu G, et al. Soluble CD23 reliably reflects disease activity in B-cell chronic lymphocytic leukemia. Journal of Clinical Oncology 1994;12:2146-52.

21. Sarfati M, Chevret S, Chastang C, Biron G, Stryckmans P, Delespesse G, Binet JL, Merle-Beral H, Bron D. Prognostic importance of serum soluble CD23 level in chronic lymphocytic leukemia. Blood 1996;88:4259-64.

22. Döhner H, Stilgenbauer S, Benner A, Leupolt E, Kröber A, Bullinger L, Döhner K, Bentz M, Lichter P. Genomic Aberrations and Survival in Chronic Lymphocytic Leukemia. New England Journal of Medicine 2000;343:1910-6.

23. Hamblin TJ, Davis Z, Gardiner A, Oscier DG, Stevenson FK. Unmutated Ig VH Genes Are Associated With a More Aggressive Form of Chronic Lymphocytic Leukemia. Blood 1999;94:1848-54.

24. Wiestner A, Rosenwald A, Barry TS, Wright G, Davis RE, Henrickson SE, Zhao H, Ibbotson RE, Orchard JA, Davis Z, Stetler-Stevenson M, Raffeld M, Arthur DC, Marti GE, Wilson WH, Hamblin TJ, Oscier DG, Staudt LM. ZAP-70 expression identifies a chronic lymphocytic leukemia subtype with unmutated immunoglobulin genes, inferior clinical outcome, and distinct gene expression profile. Blood 2003;101:4944-1.

25. Crespo M, Bosch F, Villamor N, Bellosillo B, Colomer D, Rozman M, Marcé S, López-Guillermo A, Campo E, Montserrat E. ZAP-70 Expression as a Surrogate for Immunoglobulin-Variable-Region Mutations in Chronic Lymphocytic Leukemia. New England Journal of Medicine 2003;348:1764-75.

26. Rai KR, Peterson BL, Appelbaum FR, et al. Fludarabine Compared with Chlorambucil as Primary Therapy for Chronic Lymphocytic Leukemia. New England Journal of Medicine 2000;343:1750-7.

27. Eichhorst BF, Busch R, Hopfinger G, Pasold R, Hensel M, Steinbrecher C, Siehl S, Jäger U, Bergmann M, Stilgenbauer S, Schweighofer C, Wendtner CM, Döhner H, Brittinger G, Emmerich B, Hallek M; German CLL Study Group. ludarabine plus cyclophosphamide versus fludarabine alone in first-line therapy of younger patients with chronic lymphocytic leukemia. Blood 2006;107:885-91.

28. Catovsky D, Richards S, Matutes E, Oscier D, Dyer MJ, Bezares RF, Pettitt AR, Hamblin T, Milligan DW, Child JA, Hamilton MS, Dearden CE, Smith AG, Bosanquet AG, Davis Z, Brito-Babapulle V, Else M, Wade R, Hillmen P; UK National Cancer Research Institute (NCRI) Haematological Oncology Clinical Studies Group; NCRI Chronic Lymphocytic Leukaemia Working Group.
Assessment of fludarabine plus cyclophosphamide for patients with chronic lymphocytic leukaemia (the LRF CLL4 Trial): a randomised controlled trial. The Lancet 2007;370:230-9.

29. Flinn IW, Neuberg DS, Grever MR, Dewald GW, Bennett JM, Paietta EM, Hussein MA, Appelbaum FR, Larson RA, Moore DF Jr, Tallman MSFlinn IW, Neuberg DS, Grever MR, Dewald GW, Bennett JM, Paietta EM, Hussein MA, Appelbaum FR, Larson RA, Moore DF Jr, Tallman MS. Phase III Trial of Fludarabine Plus Cyclophosphamide Compared With Fludarabine for Patients With Previously Untreated Chronic Lymphocytic Leukemia: US Intergroup Trial E2997. Journal of Clinical Oncology 2007;25:793-8.

30. Tam CS, O'Brien S, Wierda W, Kantarjian H, Wen S, Do KA, Thomas DA, Cortes J, Lerner S, Keating MJ. Longterm results of the fludarabine, cyclophosphamide, and rituximab regimen as initial therapy of chronic lymphocytic leukemia. Blood 2008;112:975-80.

31. Hallek M, Fischer K, Fingerle-Rowson G, Fink AM, Busch R, Mayer J, Hensel M, Hopfinger G, Hess G, von Grünhagen U, Bergmann M, Catalano J, Zinzani PL, Caligaris-Cappio F, Seymour JF, Berrebi A, Jäger U, Cazin B, Trneny M, Westermann A, Wendtner CM, Eichhorst BF, Staib P, Bühler A, Winkler D, Zenz T, Böttcher S, Ritgen M, Mendila M, Kneba M, Döhner H, Stilgenbauer S; International Group of Investigators; German Chronic Lymphocytic Leukaemia Study Group. Addition of rituximab to fludarabine and cyclophosphamide in patients with chronic lymphocytic leukaemia: a randomised, open-label, phase 3 trial. The Lancet 2010;376:1164-74.

32. Fischer K, Cramer P, Stilgenbauer S, et al. Bendamustine Combined with Rituximab (BR) in First-Line Therapy of Advanced CLL: A Multicenter Phase II Trial of the German CLL Study Group (GCLLSG). ASH Annual Meeting Abstracts 2009;114:3382-91.

33. Bosch F, Abrisqueta P, Villamor N, Terol MJ, GonzálezBarca E, Ferra C, González Diaz M, Abella E, Delgado J, Carbonell F, García Marco JA, Escoda L, Ferrer S, Monzó E, González Y, Estany C, Jarque I, Salamero O, Muntañola A, Montserrat E. A New, Highly Active Chemoimmunotherapy Regimen for Chronic Lymphocytic Leukemia. Journal of Clinical Oncology 2009;27:4578-84.

34. Reynolds C, Di Bella N, Lyons RM, et al. Phase III Trial of Fludarabine, Cyclophosphamide, and Rituximab Vs. Pentostatin, Cyclophosphamide, and Rituximab in B-Cell Chronic Lymphocytic Leukemia. ASH Annual Meeting Abstracts 2008;112:327.

35. Rabinowe SN, Soiffer RJ, Gribben JG, Daley H, Freedman AS, Daley J, Pesek K, Neuberg D, Pinkus G, Leavitt PR, et al. Autologous and allogeneic bone marrow transplantation for poor prognosis patients with B-cell chronic lymphocytic leukemia. Blood 1993;82:1366-76.

36. Gribben JG, Zahrieh D, Stephans K, et al. Autologous and allogeneic stem cell transplantations for poor-risk chronic lymphocytic leukemia. Blood 2005;106:4389-96.

37. Milligan DW, Fernandes S, Dasgupta R, Davies FE, Matutes E, Fegan CD, McConkey C, Child JA, Cunningham D, Morgan GJ, Catovsky D; National Cancer Research Institute Haematological Studies Group Results of the MRC pilot study show autografting 
Mc Clanahan et al.

for younger patients with chronic lymphocytic leukemia is safe and achieves a high percentage of molecular responses. Blood 2005;105:397-404.

38. McClanahan F, Stilgenbauer S, Schmitz N, et al. Secondary malignancies after early autologous stem cell transplantation in genetically poor-risk chronic lymphatic leukemia: results from the German CLL Study Group (GCLLSG) CLL3 trial. Haematologica 2009;94(Suppl. 3):iwCLL meeting abstracts, abstract 8.9, 76 .

39. Michallet M, Dreger P, Sutton L, Brand R, Richards S, van Os M, Sobh M, Choquet S, Corront B, Dearden C, Gratwohl A, Herr W, Catovsky D, Hallek M, de Witte T, Niederwieser D, Leporrier M, Milligan D; EBMT Chronic Leukemia Working Party. Autologous hematopoietic stem cell transplantation in chronic lymphocytic leukemia: results of European intergroup randomized trial comparing autografting versus observation. Blood 2010;117:1516-21.

40. Moreno C, Villamor N, Colomer D, Esteve J, Giné E, Muntañola A, Campo E, Bosch F, Montserrat E. Clinical significance of minimal residual disease, as assessed by different techniques, after stem cell transplantation for chronic lymphocytic leukemia. Blood 2006;107:4563-9.

41. Ritgen M, Stilgenbauer S, von Neuhoff N, Humpe A, Brüggemann M, Pott C, Raff T, Kröber A, Bunjes D, Schlenk R, Schmitz N, Döhner H, Kneba M, Dreger P. Graft-versus-leukemia activity may overcome therapeutic resistance of chronic lymphocytic leukemia with unmutated immunoglobulin variable heavy-chain gene status: implications of minimal residual disease measurement with quantitative PCR. Blood 2004;104:2600-2.

42. Milligan DW, Kochethu G, Dearden C, Matutes E, MacConkey C, Catovsky D; Haematological Studies Group, UK National Cancer Research Institute High incidence of myelodysplasia and secondary leukaemia in the UK Medical Research Council Pilot of autografting in chronic lymphocytic leukaemia. British Journal of Haematology 2006;133:173-5.

43. Hillmen P, Skotnicki AB, Robak T, Jaksic B, Dmoszynska A, Wu J, Sirard C, Mayer J. Alemtuzumab Compared With Chlorambucil As First-Line Therapy for Chronic Lymphocytic Leukemia. Journal of Clinical Oncology 2007;25:5616-23.

44. Stilgenbauer S, Cymbalista F, Leblond V, et al. Subcutaneous Alemtuzumab Combined with Oral Dexamethasone, Followed by Alemtuzumab Maintenance or Allo-SCT In CLL with 17p- or Refractory to Fludarabine - Interim Analysis of the CLL2O Trial of the GCLLSG and FCGCLL/MW. Blood/ ASH Annual Meeting Abstracts 2010;116:920.

45. Eichhorst BF, Busch R, Stilgenbauer S, et al. First-line therapy with fludarabine compared with chlorambucil does not result in a major benefit for elderly patients with advanced chronic lymphocytic leukemia. Blood 2009;114:3382-91.

46. Knauf WU, Lissichkov T, Aldaoud A, Liberati A, Loscertales J, Herbrecht R, Juliusson G, Postner G, Gercheva L, Goranov S, Becker M, Fricke HJ, Huguet F, Del Giudice I, Klein P, Tremmel L, Merkle K, Montillo M. Phase III Randomized Study of Bendamustine Compared With Chlorambucil in Previously Untreated
Patients With Chronic Lymphocytic Leukemia. J Clin Oncol 2009;27:4378-84.

47. Döhner H, Fischer K, Bentz M, Hansen K, Benner A, Cabot G, Diehl D, Schlenk R, Coy J, Stilgenbauer S, et al. p53 gene deletion predicts for poor survival and non-response to therapy with purine analogs in chronic B-cell leukemias. Blood 1995;85:1580-9.

48. Zenz T, Kröber A, Scherer K, Häbe S, Bühler A, Benner A, Denzel T, Winkler D, Edelmann J, Schwänen C, Döhner H, Stilgenbauer S. Monoallelic TP53 inactivation is associated with poor prognosis in chronic lymphocytic leukemia: results from a detailed genetic characterization with long-term follow-up. Blood 2008;112:3322-9.

49. Zenz T, Eichhorst B, Busch R, et al. TP53 Mutation and Survival in Chronic Lymphocytic Leukemia. Journal of Clinical Oncology 2010;28:4473-9.

50. Stilgenbauer S, Zenz T. Understanding and Managing Ultra High-Risk Chronic Lymphocytic Leukemia. Hematology 2010;2010:481-8.

51. Oscier D, Wade R, Davis Z, Morilla A, Best G, Richards S, Else M, Matutes E, Catovsky D; Chronic Lymphocytic Leukaemia Working Group, UK National Cancer Research Institute. Prognostic factors identified three risk groups in the LRF CLL4 trial, independent of treatment allocation. Haematologica 2010;95:1705-12.

52. Keating MJ, O'Brien S, Lerner S, Koller C, Beran M, Robertson LE, Freireich EJ, Estey E, Kantarjian H. LongTerm Follow-Up of Patients With Chronic Lymphocytic Leukemia (CLL) Receiving Fludarabine Regimens as Initial Therapy. Blood 1998;92:1165-71.

53. Keating MJ, Wierda WG, Tam CS, et al. Long Term Outcome Following Treatment Failure of FCR Chemoimmunotherapy as Initial Therapy for Chronic Lymphocytic Leukemia. ASH Annual Meeting Abstracts 2009;114:2381.

54. Zenz T, Busch R, Fink A, et al. Genetics of Patients with F-Refractory CLL or Early Relapse After FC or FCR: Results From the CLL8 Trial of the GCLLSG. ASH Annual Meeting Abstracts 2010;116:2427.

55. Dreger P, Corradini P, Kimby E, Michallet M, Milligan D, Schetelig J, Wiktor-Jedrzejczak W, Niederwieser D, Hallek M, Montserrat E; Chronic Leukemia Working Party of the EBMT. Indications for allogeneic stem cell transplantation in chronic lymphocytic leukemia: the EBMT transplant consensus. Leukemia 2007;21:12-7.

56. Stilgenbauer S, Zenz T, Winkler D, Bühler A, Schlenk RF, Groner S, Busch R, Hensel M, Dührsen U, Finke J, Dreger P, Jäger U, Lengfelder E, Hohloch K, Söling U, Schlag R, Kneba M, Hallek M, Döhner H; German Chronic Lymphocytic Leukemia Study Group. Subcutaneous Alemtuzumab in Fludarabine-Refractory Chronic Lymphocytic Leukemia: Clinical Results and Prognostic Marker Analyses From the CLL2H Study of the German Chronic Lymphocytic Leukemia Study Group. Journal of Clinical Oncology 2009;27:3994-4001.

57. Kennedy B, Rawstron A, Carter C, Ryan M, Speed K, Lucas G, Hilmen P. Campath-1H and fludarabine in combination are highly active in refractory chronic lymphocytic leukemia. Blood 2002;99:2245-7.

58. Elter T, Borchmann P, Schulz H, Reiser M, Trelle S, Schnell R, Jensen M, Staib P, Schinköthe T, Stützer H, 
Rech J, Gramatzki M, Aulitzky W, Hasan I, Josting A, Hallek M, Engert A. Fludarabine in Combination With Alemtuzumab Is Effective and Feasible in Patients With Relapsed or Refractory B-Cell Chronic Lymphocytic Leukemia: Results of a Phase II Trial. Journal of Clinical Oncology 2005;23:7024-31.

59. Wierda WG, Kipps TJ, Mayer J, Stilgenbauer S, Williams CD, Hellmann A, Robak T, Furman RR, Hillmen P, Trneny M, Dyer MJ, Padmanabhan S, Piotrowska M, Kozak T, Chan G, Davis R, Losic N, Wilms J, Russell CA, Osterborg A; Hx-CD20-406 Study Investigators. Ofatumumab As Single-Agent CD20 Immunotherapy in FludarabineRefractory Chronic Lymphocytic Leukemia. Journal of Clinical Oncology 2010;28:1749-55.

60. Ben-Bassat I, Raanani P, Gale RP. Graft-versus-leukemia in chronic lymphocytic leukemia. Bone Marrow Transplant 2007;39:441-6.

61. Schetelig J, Thiede C, Bornhauser M, Schwerdtfeger R, Kiehl M, Beyer J, Sayer HG, Kroger N, Hensel M, Scheffold C, Held TK, Hoffken K, Ho AD, Kienast J, Neubauer A, Zander AR, Fauser AA, Ehninger G, Siegert W; Cooperative German Transplant Study Group. Evidence of a Graft-Versus-Leukemia Effect in Chronic Lymphocytic Leukemia After Reduced-Intensity Conditioning and Allogeneic Stem-Cell Transplantation: The Cooperative German Transplant Study Group. Journal of Clinical Oncology 2003;21:2747-53.

62. Dreger P, Brand R, Hansz J, Milligan D, Corradini P, Finke J, Deliliers GL, Martino R, Russell N, Van Biezen A, Michallet M, Niederwieser D; Chronic Leukemia Working Party of the EBMT. Treatment-related mortality and graft-versus-leukemia activity after allogeneic stem cell transplantation for chronic lymphocytic leukemia using intensity-reduced conditioning. Leukemia 2003;17:841-8.

63. Pavletic SZ, Khouri IF, Haagenson M, King RJ, Bierman PJ, Bishop MR. Unrelated donor marrow transplantation for B-cell chronic lymphocytic leukemia after using myeloablative conditioning: results from the Center for International Blood and Marrow Transplant research. J Clin Oncol 2005;23:5788-94.

64. Sorror ML, Maris MB, Sandmaier BM, Storer BE, Stuart MJ, Hegenbart U, Agura E, Chauncey TR, Leis J, Pulsipher M, McSweeney P, Radich JP, Bredeson C, Bruno B, Langston A, Loken MR, Al-Ali H, Blume KG, Storb R, Maloney DG. Hematopoietic Cell Transplantation After Nonmyeloablative Conditioning for Advanced Chronic Lymphocytic Leukemia. Journal of Clinical Oncology 2005;23:3819-29.

65. Khouri IF, Saliba RM, Admirand J, O'Brien S, Lee MS, Korbling M, Samuels BI, Giralt S, Lima de M, Keating MJ, Champlin RE, Bueso-Ramos C. Graft-versusleukaemia effect after non-myeloablative haematopoi- etic transplantation can overcome the unfavourable expression of ZAP-70 in refractory chronic lymphocytic leukaemia. Br J Haematol 2007;137:355-63.

66. Brown JR, Kim HT, Li S, Stephans K, Fisher DC, Cutler C, Ho V, Lee SJ, Milford EL, Ritz J, Antin JH, Soiffer RJ, Gribben JG, Alyea EP. Predictors of Improved Progression-Free Survival After Nonmyeloablative Allogeneic Stem Cell Transplantation for Advanced Chronic Lymphocytic Leukemia. Biology of blood and marrow transplantation: journal of the American Society for Blood and Marrow Transplantation 2006;12:1056-64.

67. Sorror ML, Storer BE, Sandmaier BM, Maris M, Shizuru J, Maziarz R, Agura E, Chauncey TR, Pulsipher MA, McSweeney PA, Wade JC, Bruno B, Langston A, Radich J, Niederwieser D, Blume KG, Storb R, Maloney DG. Five-Year Follow-Up of Patients With Advanced Chronic Lymphocytic Leukemia Treated With Allogeneic Hematopoietic Cell Transplantation After Nonmyeloablative Conditioning. Journal of Clinical Oncology 2008;26:4912-20.

68. Delgado J, Thomson K, Russell N, Ewing J, Stewart W, Cook G, Devereux S, Lovell R, Chopra R, Marks DI, Mackinnon S, Milligan DW; British Society of Blood and Marrow Transplantation. Results of alemtuzumabbased reduced-intensity allogeneic transplantation for chronic lymphocytic leukemia: a British Society of Blood and Marrow Transplantation Study. Blood 2006;107:1724-30.

69. Schetelig J, van Biezen A, Brand R, Caballero D, Martino R, Itala M, García-Marco JA, Volin L, Schmitz N, Schwerdtfeger R, Ganser A, Onida F, Mohr B, Stilgenbauer S, Bornhäuser $\mathrm{M}$, de Witte $\mathrm{T}$, Dreger $\mathrm{P}$. Allogeneic Hematopoietic Stem-Cell Transplantation for Chronic Lymphocytic Leukemia With 17p Deletion: A Retrospective European Group for Blood and Marrow Transplantation Analysis. Journal of Clinical Oncology 2008;26:5094-100.

70. Dreger P, Döhner H, Ritgen M, Böttcher S, Busch R, Dietrich S, Bunjes D, Cohen S, Schubert J, Hegenbart U, Beelen D, Zeis M, Stadler M, Hasenkamp J, Uharek L, Scheid C, Humpe A, Zenz T, Winkler D, Hallek M, Kneba M, Schmitz N, Stilgenbauer S; German CLL Study Group. Allogeneic stem cell transplantation provides durable disease control in poor-risk chronic lymphocytic leukemia: long-term clinical and MRD results of the German CLL Study Group CLL3X trial. Blood 2010;116:2438-47.

71. Zenz T, Dreger P, Dietrich S, et al. Allogeneic Stem Cell Transplantation Can Overcome the Adverse Prognostic Impact of TP53 Mutation In Chronic Lymphocytic Leukemia (CLL): Results From the GCLLSG CLL3x Trial. ASH Annual Meeting Abstracts 2010;116:2357. 